\title{
Trusting the Dependent Judiciary: Evidence From ECUADOR $^{*}$
}

\author{
Confianza en la justicia: evidencia desde Ecuador
}

\author{
PAULA ARMENDÁRIZ \\ University of Minnesota, United States
}

\begin{abstract}
The literature on judicial politics has assumed that judicial independence and trust in the judiciary go hand in hand. Based on evidence from Ecuador, I show that citizens' trust and support for the judiciary can increase despite decreasing levels of judicial independence, which I argue is largely driven by citizens' approval of executive performance in office. Popular presidents send cues to their constituents regarding how and why the judiciary should be trusted, despite its institutional flaws. These results open the possibility to question whether public trust in the judiciary necessarily stems from the presence of independent judicial institutions.
\end{abstract}

Keywords: judicial politics, public opinion, trust in the judiciary, Latin America.

\section{RESUMEN}

La literatura en política judicial ha asumido que la independencia judicial y la confianza ciudadana en la justicia son dos elementos que van de la mano. Sin embargo, pocos han cuestionado esta relación. Utilizando el caso ecuatoriano, esta investigación muestra que los ciudadanos pueden incrementar su confianza en la justicia aun cuando ésta no sea independiente. Este fenómeno se explica por un incremento en las evaluaciones al trabajo del ejecutivo. Presidentes populares pueden mandar señales al pueblo sobre cómo y por qué la justicia merece ser confiada, a pesar de sus fallas. Estos resultados abren la posibilidad de cuestionar si la confianza ciudadana en la justicia nace necesariamente de la independencia de sus instituciones.

Palabras clave: política judicial, opinión pública, confianza en la justicia, América Latina. 


\section{JUDICIAL DEPENDENCE AND TRUST}

In January 2016, Ecuador's president - Rafael Correa - announced that citizens' trust in the judiciary had increased significantly. Data from the AmericasBarometer placed Ecuador second among all South American countries on citizens' trust in the judicial system. At the same time, non-governmental organizations and some domestic political actors denounced that Ecuador's judiciary had completely fallen under the power of the president. Therefore, Ecuadorians' increasing support for the judiciary, even when it has clearly become less independent, is puzzling.

Based on the Ecuadorian case, I argue that support for the executive shapes citizens' trust in the judiciary, regardless of the level of institutional independence. Such phenomena are prevalent in delegative democracies, where the president is seen as the embodiment of the nation and the main custodian of its interests and where horizontal accountability is weak (O'Donnell 1994). In these countries - such as Ecuador - there is often an authoritarian culture characterized by a history of statism and centralization of power that has led to the formation of a culture where citizens depend on their immediate authorities to make decisions; rather than one in which individuals are self-empowered (Heras 2004).

In these contexts, the president sends cues to citizens to guide their evaluations of the country's courts. By constantly reminding citizens that courts are there to serve the people and not the interests of the elites, the incumbent drives individuals' trust in the judiciary even if its independence has been severely damaged. Hence, it is citizens' approval of the executive what drives their increased trust in the (dependent) judiciary.

I test my argument based on the Ecuadorian case and its recent experience with judicial independence and public support for the judiciary. In 2011, Ecuador's president - Rafael Correa - implemented a judicial reform to (supposedly) improve efficiency, services, and combat corruption. At the same time, this reform led to decreasing levels of judicial independence as judges were removed and appointed at the incumbent's will. And yet, while judicial independence declined, citizen support for the judiciary increased. Naturally, one would argue that Ecuadorians' support increased because the reform represented improvements to the judicial system. However, such arguments are incorrect. Citizens that report having any dealings with courts showed less - not more - trust in the judiciary. Clearly, something else is driving this puzzling relationship. I contend that citizens' increasing approval of Correa's performance as president guides their evaluations of the judiciary, even when its institutions are flawed and have become less independent. To support my argument, I use public opinion data for Ecuador from 2004 to 2019.

I focus my analysis on a comparison of the periods before and after the $2011 \mathrm{im}$ plementation of judicial reform. This allows me to explain the phenomenon of increasing citizen support for a judiciary that has become less independent. The 
evidence largely supports my argument: citizens' approval of the incumbent's performance predicts increasing levels of trust in the judiciary, and this relationship is substantially stronger after judicial reform. While executive approval is generally related to citizens' evaluations of the judiciary, its effect doubles in the post-reform period. This evidence shows that popular presidents can use executive-driven reforms to shape public opinion towards the judiciary, even when such reforms have rendered the judicial system less independent.

Moreover, although the reform sought to improve the judiciary's services, I find that citizens who report having any dealings with courts show less trust in the judiciary than those without such interactions. Skeptics would argue that my argument misses the fact that citizens evaluate incumbents based on their perceptions of the national economy, and that national economy is truly what is driving support for the judiciary. However, citizens' retrospective evaluations of national (or one's personal) economy is not predictive of trust in the judiciary, while presidential approval is.

My study has important implications for the literature on judicial legitimacy. Theoretically, public support for the judiciary and judicial independence should go hand in hand. Individuals should support courts that are depoliticized, for this assures that these will act independently from politicians. Contrary to the conventional wisdom, I show that, under certain circumstances, citizens can and do trust a highly dependent judiciary (Caldeira and Gibson 1992; Cann and Yates 2008).

The paper is organized as follows: the next section reviews the literature on citizen support for the judiciary. Following that, I present Ecuador's experience with judicial independence and citizens' trust in the judiciary. In this section, I focus on the government of Rafael Correa, his subsequent reform of the judiciary and the effects that it had on both judicial independence and public trust in the judiciary. I then present evidence from public opinion data to show the relationship between executive approval and increasing trust in the judiciary. Here, I also discuss the processes through which these two variables are related. Finally, I discuss the implications of my analysis for scholars interested in the study of citizens' trust in judicial and other institutions.

\section{WHAT WE KNOW ABOUT PUBLIC SUPPORT FOR THE JUDICIARY}

Citizen trust in the legal system is one crucial aspect of legitimacy (Caldeira and Gibson 1992), and the judiciary is a fundamental institution for democracy and the rule of law (Helmke and Rios-Figueroa 2011). Unlike other governmental institutions, the judiciary does not have an electoral connection to its constituents and thus it must construct reservoirs of support through other - non-electoral - links (Benesh 2006). Judicial legitimacy is often defined as a deeply held support for the judiciary, even when it produces outcomes that are unpopular 
or not beneficial to individuals (Caldeira and Gibson 1995; Tyler 2006), which has also been termed diffuse support (Easton 1975).

Several scholars in the United States and Europe have unveiled the factors that give rise to judicial legitimacy. Some argue that the values of liberty and freedom are important predictors of legitimacy for both the Supreme Court of the United States (Caldeira and Gibson 1992) and for state courts (Cann and Yates 2008). Others have shown that political and legal knowledge, political interest, and repeated experience with the judicial system increase citizen support for state courts (Benesh 2006; Cann and Yates 2008). Scholars investigating judicial systems in Europe have found that support for the European Court of Justice (ECJ) is shaped by people's attitudes towards the European Union and their adherence to values of freedom and liberty (Caldeira and Gibson 1995).

Beyond the American and European contexts, scholars have sought to explore the determinants of judicial legitimacy across both established and developing democracies. These studies find that confidence in the judiciary - their proxy for diffuse support - is positively correlated with judicial independence, although the relationship is not strong (Bühlmann and Kunz 2011). Research focused in Latin America has shown that, on average, Latin Americans are more likely to support their judiciaries when they do not perceive corruption in their political systems, when they have strong liberal democratic values, a normative commitment to the rule of law, and when they do not support presidentialism (Salzman and Ramsey 2013; Walker 2016).

Most of the works cited above find some relationship between support for the judiciary and judicial independence. In consequence, they assume that if a judiciary is independent from the interference of other governmental branches people will be able to perceive judicial independence - somehow accurately - and hence, conclude that the judiciary is trustworthy. Yet, scholars have overlooked the possibility that citizens can show strong, positive support towards a judiciary that is captured by one of the government branches.

Taking advantage of this unexplored area, I assess the possibility that judicial independence and support for the judiciary do not necessarily go hand in hand. I contend that, in delegative democracies, citizens may support highly dependent judiciaries. To show how this might be the case, I draw upon the case of Ecuador and its experience with judicial independence and citizen support for the judiciary. I suggest this relationship is driven by citizens' approval of the incumbent president. This allows me to shed light on the conditions under which we might observe that citizen support for the judiciary does not stem from its levels of independence.

The Ecuadorian case does not follow conventional expectations that decreasing levels of judicial independence decrease citizen trust in the judiciary, and thus can teach us something regarding citizen trust in judicial institutions. Ecuador's judicial independence has historically waxed and waned; however, 
former president Rafael Correa's 2011 judicial reform further undermined it to levels on par with those before the transition to democracy. Surprisingly, decreasing levels of judicial independence after the reform have gone hand in hand with increased citizen support for the judiciary. This puzzling phenomenon suggests a relationship with the country's political changes. What exactly happened that made Ecuadorians trust their judicial system more, even though there was clear executive interference with the judiciary?

\section{A HIGHLY TRUSTED BUT CAPTURED JUDICIARY}

"People will say we want to get our hands on the courts. Yes, of course we want to get our hands on them, for the sake of Ecuadorians! We need to change the judicial system, fellow citizens." (El Universo 2011). In one of his weekly shows that former president Rafael Correa held every Saturday - also known as "Sabatinas"-, he announced his decision to call for a national referendum to amend the recently adopted Constitution. According to the president, the main goal was to introduce much needed reforms to combat corruption and the poor provision of services in many government institutions. As a result, the president called for a national referendum that proposed changing the judicial system, citizen safety, the banking system, and the regulation of the media. Although these were certainly important and necessary reforms to improve these institutions, scholars suspect the main goal of the referendum was for Correa to obtain a "free pass in the designation of the members of the Judicial Council and the National Court of Justice." (Freidenberg 2012,140) Clearly, such changes implied that judicial independence would be severely harmed as the reform implied that Correa had absolute power to decide who will be appointed to the highest positions of Ecuador's judicial system.

The referendum generated strong reactions from the opposition and international NGOs. Even some members of Correa's party (i.e., Alianza País) showed their disapproval and deserted their party affiliation (Freidenberg 2012). These groups condemned Correa's attempt to concentrate power and warned that, if the reforms were approved, they would seriously undermine the judiciary's independence and its ability to act as a neutral actor (Basabe-Serrano 2013). Despite this confrontational scenario, most citizens showed their support for the changes proposed to the judicial system. Polls conducted by CEDATOS - a private survey firm in Ecuador - showed that 52\% of Ecuadorians approved of the national referendum. Most importantly, an astonishing $56 \%$ of people approved the government's direct intervention in the judicial system of the country. ${ }^{1}$ Clearly, some citizens thought that Correa's meddling with justice was something that the country needed. 
The 2011 national referendum gave a solid victory to Correa with 54\% of the people approving the judicial reform. The reform's implementation began in July 2011 and had three major goals: to improve the efficiency of the courts in processing cases, to combat corruption and unequal treatment under the law, and to solve delays in the judiciary that had resulted in millions of unprocessed cases (Consejo de la Judicatura 2013). To achieve these goals, the government allocated an important amount of its budget to the judiciary (Basabe-Serrano 2013). Moreover, an international team of law experts was invited to oversee the judicial reform and write reports about its execution and results (Pásara 2014).

According to government reports, the reform resulted in an improvement in the efficiency with which courts processed cases, and the number of judges, public defenders, and prosecutors per 100,000 citizens increased. Additionally, the investment in the judiciary improved its technology and the quality of services available for citizens (Consejo de la Judicatura 2015). Nevertheless, in the process of carrying out these improvements, the reform also gave the executive direct leverage in the selection of judges to the main institutions of the judiciary. A new judicial council made up in its majority by former members of Correa's administration was created. Between 2011 and 2013 this council appointed 1,430 judges, suspended 273, and removed 380. Moreover, three NGOs - the Due Process of Law Foundation, De Justicia, and the Institute for Legal Defense - affirmed that since the reform began there has been routine executive interference with judicial decisions, as well as misuse of the penal and judicial systems to target individuals and judges who question the government's policies (Human Rights Watch 2016).

To better present how judicial independence has changed in the country over the years, Figure 1 shows judicial independence data for Ecuador from 1948 to 2015 as measured by Linzer \& Staton (2015). ${ }^{2}$ Figure 2 shows average scores from 2004 to 2016 for citizens' beliefs about whether courts guarantee a fair trial, using data from the AmericasBarometer. After judicial independence reached its peak in 1978 with Ecuador's return to democracy, it has mostly been decreasing although not monotonically. 
Figure 1. Judicial Independence 1948-2015

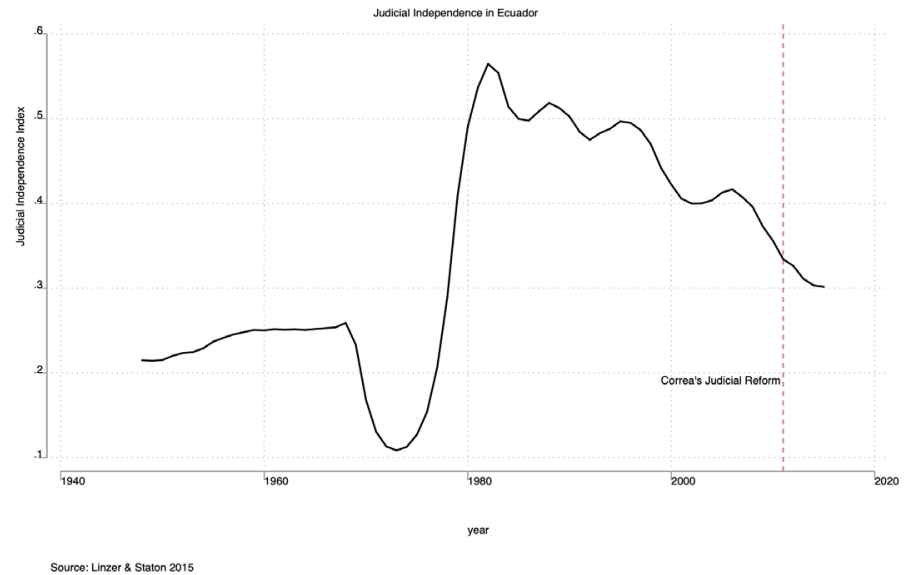

Note that the data shows that after the implementation of Correa's judicial reform in 2011, judicial independence continued to decrease. Furthermore, estimates from the World Justice Project (WJP) show that judicial independence has continued to decline. For instance, the WJP's indicator of "Constraints on Government's Powers" for Ecuador shows that on a 0 to 1 scale the country has decreased its score from 0.41 in 2013 to 0.35 in 2016. Conventional wisdom tells us that such declines in judicial independence should lead to decreasing levels of support for the judiciary, but this is not the case.

Figure 2. Support for the Judiciary

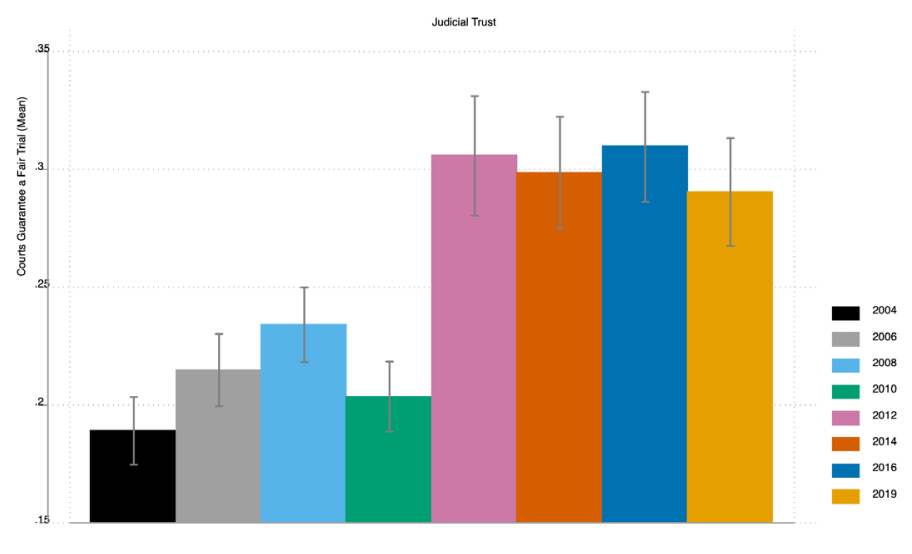


Figure 2 shows the percentage of people saying that they believe Ecuadorian courts guarantee a fair trial. As Figure 2 shows, despite decreasing judicial independence Ecuadorians' trust in the judiciary has substantially increased. Once Correa implemented his judicial reform in 2011, citizens' beliefs that courts guarantee a fair trial have increased and become stable, remaining higher than in years prior to the reform. Moreover, this is not an artifact of the type of question asked to respondents or the survey used. According to data from the AmericasBarometer, in 2010, 24\% of respondents said that they trusted the Ecuadorian justice system. This percentage increased to $36 \%$ in 2014, a 10-percentage increase in just four years. The same incremental levels of support for the judiciary are present when examining the question given to respondents regarding how much trust they place in the justice system. Moreover, a 2012 report from the Ecuadorian Institute of Statistics (INEC) showed that 52\% of the people believed that the new courts were doing a good job (Consejo de la Judicatura 2015).

To explain this puzzling relationship, I argue that this phenomenon is driven by citizens' evaluations of the incumbent. Presidents who enjoy high levels of public support are also able to use executive-driven reforms of government institutions to send cues to citizens regarding why such reforms signify an improvement, even when these may harm democracy and the rule of law.

Correa's popularity allowed him to politicize governmental institutions and judicial reforms, which he subsequently used to mold public opinion. For one, Rafael Correa was Ecuador's most popular president with an average approval rating equal to 56\% (Córdova 2019). Such high levels of approval allowed him to gather public support for most of his political goals including the 2011 judicial reform. For instance, as soon as he took office Correa advanced the idea of establishing a constituent assembly to write a new constitution. In the national referendum, $82 \%$ voted in favor of a constituent assembly while only $12 \%$ rejected it. Throughout his presidency, citizens voted in two presidential elections, two legislative elections, two national referenda, and one national plebiscite, all of which resulted in successes for Correa and his party.

Second, during Correa's tenure most governmental institutions were politicized. This implies that the other government branches (e.g., congress, courts, and the Consejo de Participación Ciudadana) were not independent from the executive and, in fact, served at Correa's will (Basabe-Serrano and Martínez 2014). Correa was able to use his popularity to shape public opinion towards these institutions, despite their lack of independence from the executive. In other words, the politization of the judiciary (and of other institutions) meant that Correa not only had the power to change these institutions, he also had the power to influence how people felt towards the judiciary and whether it should be trusted.

Third, Correa also shaped public opinion towards the judiciary by sending cues to citizens telling them that his government, and by implication its judicial 
institutions, were there to serve the people - and not traditional elites. Correa did this with the aid of a major media apparatus owned and operated by the government. Correa's government owned twenty-one different media properties that included fourteen impounded outlets, three public ones and four at the state level (Fundamedios 2013). Through different programs and propagan$\mathrm{da}$, these outlets constantly communicated government initiatives including, of course, the government's investments in the judiciary (de la Torre 2013).

Additionally, Correa used to hold weekly TV and radio shows that were broadcast every Saturday from different towns and cities throughout the country. These were spaces in which Correa engaged in a direct dialogue with Ecuadorians about the success of his political reforms in terms of creating social justice. For instance, in one of his "Sabatinas," Correa criticized a Human Rights Watch report that affirmed that the 2011 judicial reform undermined judicial independence in the country: "Thank God nobody believes these people, because polls show that one of the areas with the greatest levels of satisfaction is the judicial system." (SECOM 2016) By permanently communicating to citizens that Ecuadorian courts are trustworthy, Correa used citizens' approval of his performance to increase their trust in the judiciary. These strategies combined with the politization of government institutions allowed Correa to mold public opinion towards the judiciary, especially when it clearly lacked judicial independence.

If my argument is correct, then we should observe the following. First, all else equal, the effect of executive approval on citizens' trust in the judiciary should significantly increase in the years following the judicial reform. In much of Latin America, executive approval tends to be a significant predictor of citizens' trust in government institutions (Booth and Seligson 2009; Carlin and Singer 2011). I still expect executive approval in the pre-reform period to matter for judicial support; however, due to Correa's efforts to shape perceptions of his judicial reform as something positive for the functioning of the judiciary, I argue that this relationship should be substantially stronger after the reform took place. That is, I expect to observe public trust in the judiciary increase in the years following Correa's judicial reform. If this relationship is found in the data, this would render support for my argument that Ecuadorians' approval of Correa's performance in office is driving their trust in the judiciary.

Second, if increased support for the judiciary is mostly a function of presidential approval, and not of improved provision of judicial services, then we should observe that experience with courts should not lead to greater public trust in the judiciary. If support in the judiciary is dependent on presidential approval, contact with the judiciary shouldn't have an impact on public opinion.

Third, much research shows that citizens evaluate incumbents based on their perceptions of the national economy (Singer and Carlin 2013; Zechmeister and Zizumbo-Colunga 2013). Therefore, it could be the case that citizens are simply satisfied with the state of the economy resulting in increased trust of judicial 
institutions. Yet, if we observe that executive approval in the years post-reform is significantly higher above and beyond people's perceptions of the national economy, this would demonstrate that there is something more than mere citizen instrumental reasoning.

\section{CITIZENS' TRUST IN THE JUDICIARY: SHAPING PUBLIC OPINION}

To test my argument that approval of Correa has an effect on individual trust in the Ecuadorian judiciary, I use public opinion data from the AmericasBarometer for Ecuador from 2004 to 2019. In crafting my models, I have sought to keep them parsimonious and to include variables that cover all possible survey-years. To assess Ecuadorians' support for the judiciary, I use a question that asks citizens whether they consider that courts guarantee a fair trial. This variable is measured with a seven-point scale where 1 means completely disagree and 7 completely agree. I chose this variable instead of a measure of citizens' trust in the judicial system because I want to assess citizens' beliefs and support for the judiciary and its institutions, not only whether they trust them.

Asking people whether they think courts are fair taps onto their beliefs of whether the institutions of the judiciary should be trusted, while also assessing whether individuals think that the judiciary produces outcomes that are fair. Moreover, unlike other questions included in this survey, this question is available from 2004 until 2019 allowing me to test the extent to which Correa's judicial reform increased trust in the judiciary, compared to the period preceding the reform.

Therefore, my dependent variable of interest is Ecuadorians' perceptions that courts guarantee a fair trial. I use this variable as a proxy for people's trust in and support for the judiciary. To ease any concerns regarding my choice of using this variable, in the appendix I include a series of robustness checks where I use a question that asks citizens to what extent they trust the justice system. The results are substantively the same with this variable.

To test my hypothesis that the effect of executive approval is significantly stronger in the years following the 2011 reform, I first create a nominal variable that measures the different periods before and after judicial reform. This variable is divided into a before Correa period (2004-2006), a pre-reform period (20082010), a post-reform period (2012-2016), and a post-Correa period (2019). For executive approval, I use a measure of citizens' approval of the president's job, which ranges from 1 "very bad" to 5 "very good". I interact executive approval with the nominal reform variable. This allows me to test whether the effect of presidential popularity on people's trust in the judiciary varies across the periods before and after the reform. More importantly, this interaction allows me to see if it is specifically Correa's cueing of the judicial reform which significantly increases trust in the judiciary. 
As such, my main predictor of interest is the interaction between executive approval and the nominal reform variable. Hence, if indeed it was Correa's use of the judicial reform that which shaped public opinion of the judiciary, I should observe that the interaction between the post-reform period and executive approval is significant and positive, and only significant for the time periods in which Correa was in power.

Regarding additional theoretical confounders, I include measures of adherence to democratic values, tolerance, and victimization by corruption. For adherence to democratic values I include a question that asks: "democracy may have its problems, but it is better than any other form of government. To what extent do you agree with this statement?" This is measured on a 1 to 7 scale ranging from strongly disagree to strongly agree. Tolerance is an index formed by combining a series of questions regarding individuals' tolerance of opposition members manifesting their political views publicly. Corruption victimization is constructed using a series of questions regarding whether individuals have been asked to pay bribes when dealing with different governmental institutions. Full wording of the questions is available in the Appendix.

To rule out the possibility that experience with courts drives citizen support for the judiciary, I include a binary variable that takes on a value of 1 if the respondent reports to have any dealings with courts in the last 12 months, and 0 otherwise. To evaluate the possibility that perceptions of the economy drive judicial support, I include two separate variables for retrospective evaluations of the national and personal economy. Finally, I also incorporate a series of demographic variables: education, personal income, age, sex, and whether the respondent lives in an urban or a rural area, in the model as controls.

To ease interpretation, all the variables have been recoded to range from a minimum value of 0 to a maximum of $1 .^{3}$ To test my argument, I employ a pooledOLS model with survey design effects and fixed effects per year. To ease visualization, I only include variables that render a significant result or those that are of theoretical interest. Importantly, I run a series of robustness checks by employing an ordered logit model instead of OLS and by using respondents' trust in the judiciary as my dependent variable. The results are substantively the same, full results and robustness checks are presented in the Appendix.

Figure 3 presents the direct effects of executive approval on public trust for the judiciary. This baseline model shows that indeed, irrespective of the period, increasing levels of executive approval are related to higher beliefs that Ecuadorian courts guarantee a fair trial. Specifically, a one-unit increase in approval of the president's job while in office is related to a $16 \%$ increase in people's beliefs that courts guarantee a fair trial.

This does not imply that the variables have been dichotomized. Instead, I have maintained the structure of each variable but recoded them so that the minimum value equals 0 and the maximum value 1 , with all possible values ranging in between. 
Figure 3. Executive Approval \& Trust in the Judiciary

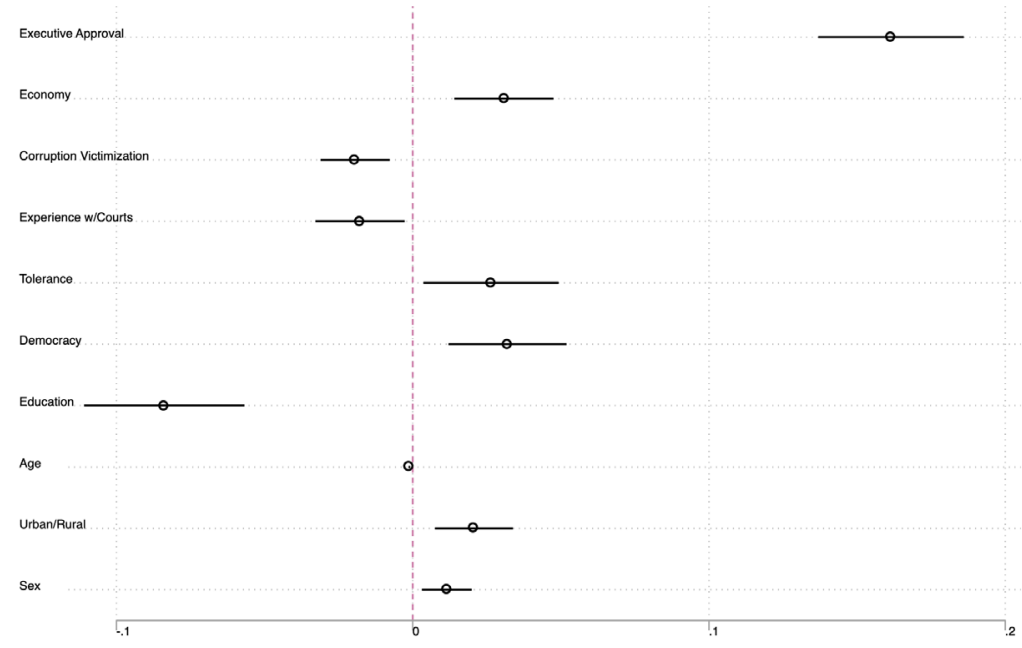

Figure 4 presents the results for my main argument, that the effect of executive approval on trust in the judiciary is stronger in the years following judicial reform. As we can see, the interaction between executive approval and the period variable is positive and significant only for the years post judicial reform. As evidenced on Figure 4, the effects of executive approval are only significant for the 2012-2016 period, showing that Correa' judicial reform shaped opinion towards the judiciary.

Figure 4. Executive Approval X Reform Periods

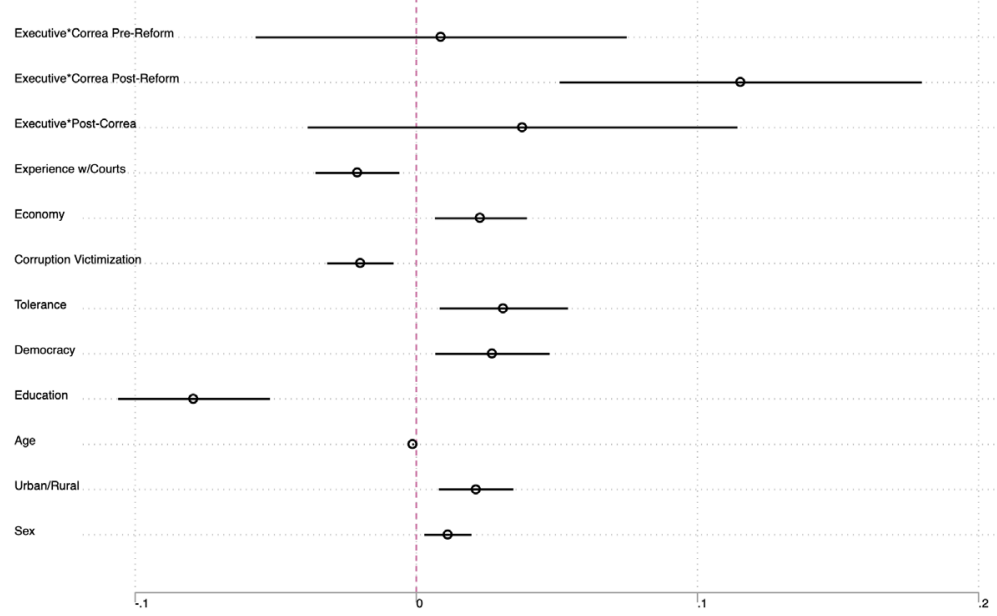


This relationship suggests that in the post-reform period, citizens form their trust in the country's courts based on how Correa used his popularity to create an image of the judiciary as an institution that is trustworthy, in spite of the fact that it had become clearly dependent on the executive branch. Given Correa's constant efforts in sending cues about how well the courts are functioning now, citizens subsequently trust a dependent judiciary.

Of equal importance are the results that I obtain for the set of controls, particularly perceptions of the national economy and experience with courts. This allows me to rule out two key alternative explanations to my argument. First, it could be the case that support for the judiciary in Ecuador and its relationship with presidential approval is driven by perceptions of the economy. Importantly, Correa's government enjoyed a growing economy during most of the years studied. Thus, citizens could be translating their evaluations of the national economy to the judiciary and this would imply that my argument is a spurious one. In that case, I should observe that perceptions of the national economy result in higher levels of judicial trust. Second, since the judicial reform also entailed an increase in government investment in the judiciary, which resulted in a modernization of its institutions, it could be the case that presidential approval is just capturing Ecuadorians having an improved experience with the reformed judiciary. In this scenario, I would expect experience with courts to be a significant predictor of trust in the judiciary. After all, if there was an improvement to the judicial system, then we should observe that citizens who have interactions with courts should also hold positive evaluations of their functioning.

Figure 5. Economy, Courts X Reform Period

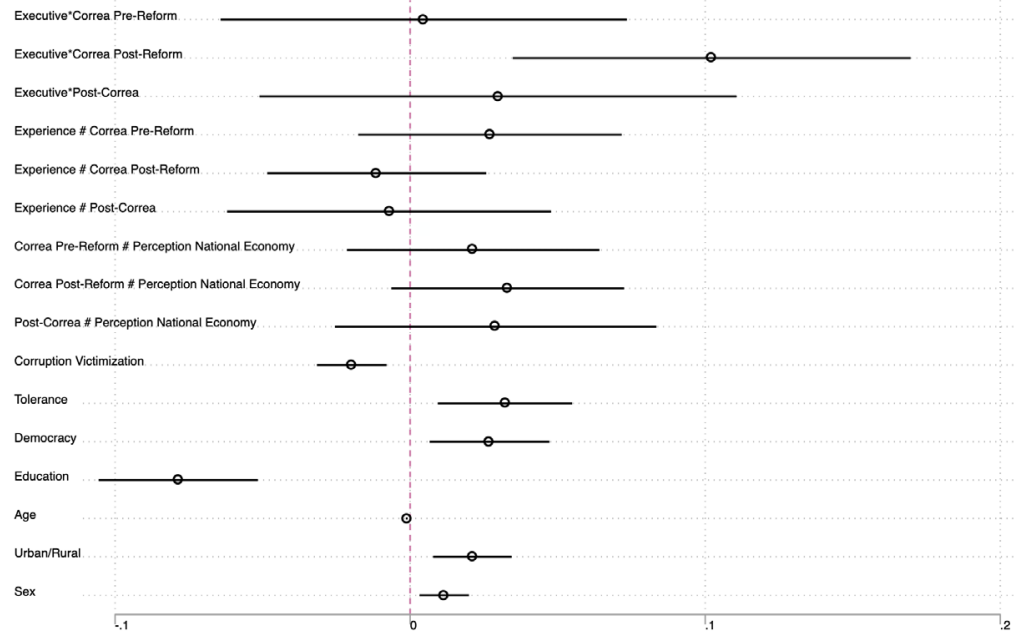


To test this, I also interact perceptions of the national economy and experience with courts with the reform period variable. This allows me to see if in the years following the judicial reform, perceptions of the economy and/or experiences with courts drive the results observed for executive approval. Figure 5 shows that neither perceptions of the national economy nor experience with courts show significant effects on people's trust in the judiciary in the years following the judicial reform. That is, the interaction between perceptions of the national economy or experience with courts with the reform period variable is not significant, for any of the time periods. These results allow me to rule out the possibility that citizens' increased trust in the judiciary is driven by a strong economic performance.

Figure 5 shows that Ecuadorians who report having any dealings with courts in the past year are less likely to believe that these guarantee a fair trial, compared to citizens who do not have dealings with courts. If anything, experiences with courts have a negative effect on trust in the judiciary. Perhaps more important to illustrate that Correa's involvement with judicial reform is what impacts public opinion is that there is no change with respect to people's dealings with courts and their level of trust in the judiciary when examining the effects across reform periods. This implies that, at a minimum, people who report having any dealings with courts in the past year have not changed their level of trust in the Ecuadorian judiciary. ${ }^{4}$

Ruling out these two arguments gives more leverage to my hypothesis that it is citizens' approval of Correa's performance and his ability to send cues to the citizenry regarding how the reform improved the judiciary that explains increased support for a captured institution. That is, under Correa the country might as well have enjoyed favorable economic conditions and his reform may have improved judicial services.

Regarding other controls, corruption victimization by, tolerance, democratic values, education, sex, age, and whether the respondent lives in an urban versus rural area also rendered significant effects. Citizens who experience less corruption when dealing with public services, those who are tolerant and value democracy, the less educated, younger, rural residents tend to have greater beliefs that courts guarantee a fair trial.

While most of these results are expected, that of respondents' education is particularly interesting. The literature on judicial politics has found that people with more education tend to have greater trust in the judiciary (Caldeira and Gibson 1992; Cann and Yates 2008). However, I find the exact opposite: people who are less educated tend to place greater trust in the judiciary. One explanation might be that more educated citizens have greater access to information

It should be noted that from my full sample of 17,972 individuals, the vast majority $(15,592)$ do not have any dealings with courts. This implies that it is a minority of the Ecuadorian sample $(2,380)$ those who report having any dealing with courts. 
and, thus, are more skeptical regarding government institutions and, hence, Correa's attempt to shape public opinion. This possibility should be explored in future research.

To get an idea of the substantive effect that presidential approval has on citizens' support for the judiciary in the post-reform period, in Figures 6 and 7 I present predictive margins across all levels of executive approval for the four periods before and after the reform. The rest of the covariates are held at their mean or modal values. ${ }^{5}$

Figure 6. Marginal Effects of Executive Approval on Reform

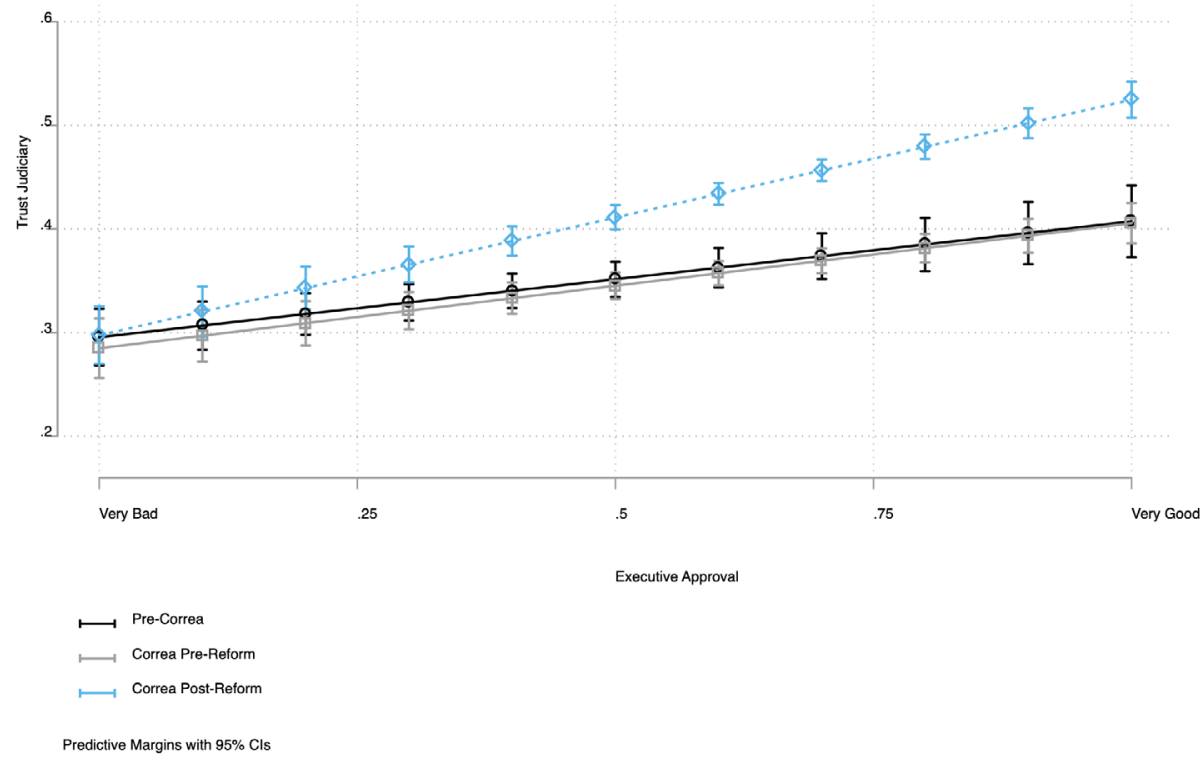


Figure 7. Marginal Effects of Executive Approval on Reform

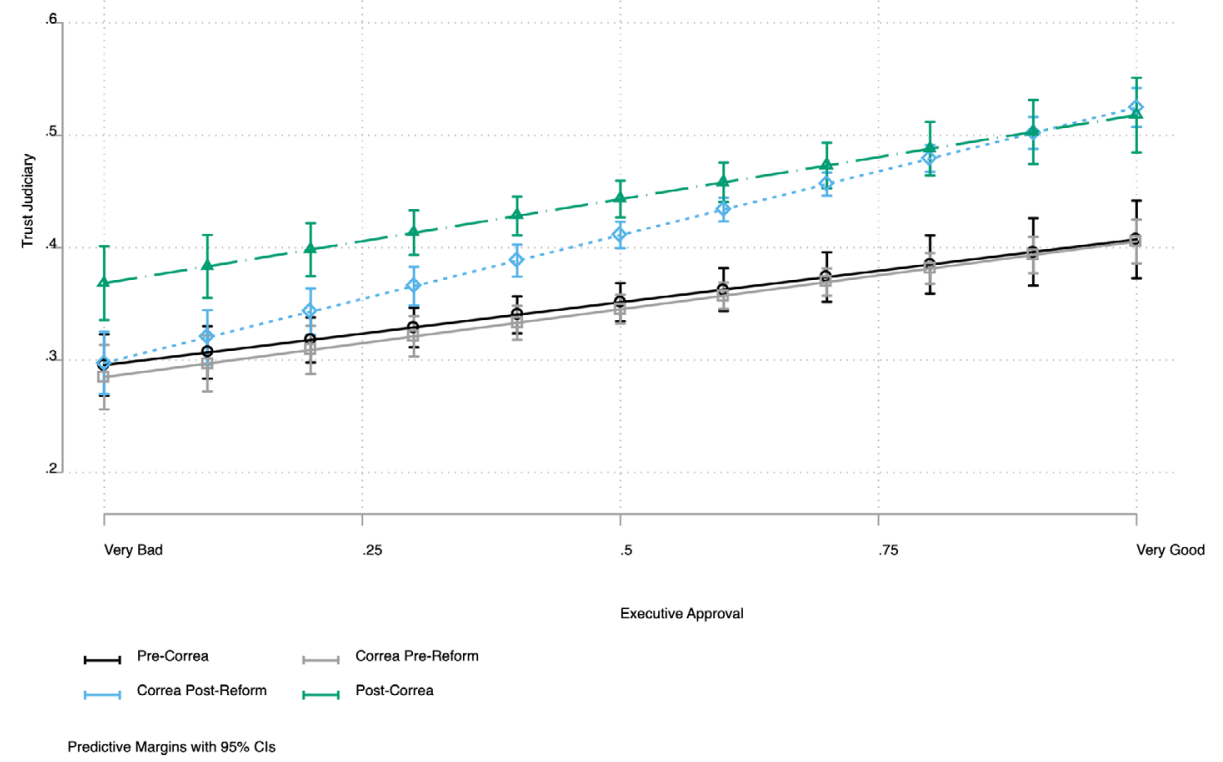

Figure 6 clearly shows that the effects of executive approval on individuals' trust in the judiciary before Correa came to power and during Correa's presidency but before the 2011 judicial reform are not significant. In the pre-Correa and in the pre-reform periods, the effect on judicial support increases by $11 \%$ when moving from the lowest to the highest level of executive approval. A non-significant effect as per the model presented in figure 5. In contrast, during the post-reform period going from the lowest to the highest level of presidential approval, the effect on people's beliefs about courts guaranteeing a fair trial increases by $24 \%$, a more than a two-fold increase compared to the pre-reform years.

Figure 7 includes the same information but including the post-Correa period. Again, the effect of executive approval on people's trust in the judiciary is not significant during this period. This is interesting because it implies that not just any president can shape public opinion of the judiciary. It takes a very popular president who has been able to send cues to citizens regarding how his political decisions are good for the country in order to influence citizens' views towards government institutions. It should be noted, however, that the effect of executive approval on public trust in the judiciary in the post-Correa period is greater than in the pre-Correa and pre-reform periods. However, the interaction for the post-Correa period and executive approval is not significant.

This evidence shows that citizens are clearly forming their evaluations of the judiciary guided by Correa's performance and his cues regarding the judicial 
system. Correa was able to use his popularity to make an important proportion of the electorate perceive that courts, now more than before, are fair. Hence, even if Ecuador's judicial system is clearly not independent, its citizens believe that courts are fair, as these institutions are perceived to be part of a government that says that it represents the people's interests.

The arguments made above imply that the incumbent sends cues to citizens regarding how to evaluate the institutions of the judiciary. I have sought to capture this by assessing the relationship between executive approval and trust in the judiciary. While the relationship that I find is strong and it allows me to rule out alternative explanations, I am assuming that citizens who highly approve of the president's performance in office are translating this into increasing trust in the judiciary because they receive cues from the incumbent. With the kind of data that I have available I cannot assess if citizens indeed perceive such cues. To get at that I would have to rely on an experimental design where individuals are primed with different messages about the judiciary's trustworthiness coming from incumbent and non-incumbent sources. I will seek to carry out this research in the near future.

\section{DISCUSSION}

The evidence presented here shows that popular presidents can effectively send cues to citizens regarding how they should evaluate the judiciary. This type of incumbents are also generally able to capture political institutions and use their popularity to mold public opinion. Through such processes, citizens perceptions of the judiciary are guided by their approval of incumbent performance and not necessarily by how independent the judiciary is from other branches of the government, as much of the literature has presumed.

The Ecuadorian case demonstrates that declining levels of judicial independence may go hand in hand with increased support for the judiciary. Ecuador has had a troubling history with judicial independence and trust in the judiciary. While judicial independence has been generally unstable - with nonmonotonic changes throughout Ecuador's history -, support for the judiciary has traditionally been low. All of this changed when Correa came to power and implemented a highly controversial judicial reform.

The reform was severely criticized by non-governmental organizations and has been reflected in declining measures of judicial independence after its implementation. Yet, Ecuadorians changed their traditional perceptions towards the judiciary. Suddenly, people were showing greater levels of support and trust in the Ecuadorian judicial system. "Trust in justice is the highest in the region, Ecuador has a $48 \%$ [of trust in the judicial system]. Trust in the judicial system places Ecuador second in the region, only Uruguay is above us." (SECOM 2016) 
In this paper, I have sought to explain the puzzling relationship between declining levels of judicial independence and increasing levels of citizen trust in the judiciary. My study shows that citizens evaluations of the judiciary may be guided by their approval of the incumbent. In such scenarios, the executive sends cues to citizens regarding how and why courts, despite their institutional flaws and lack of independence, should be trusted. Hence, how citizens rate the executive's performance positively influences their perceptions towards the judiciary, even when they would normally show very low levels of support and trust towards its institutions. These conclusions pose important questions for the literature on judicial politics, as much of it has presumed that citizen trust in the judiciary stems from its institutions being independent from other branches of the government.

This study shows that there is much to learn from the Ecuadorian case. Citizens can and do form their evaluations of their country's courts based on factors that are unrelated to how independent the judiciary is from other branches of the government. Perhaps even more important is that citizens fail to take into consideration the performance of the judiciary and its courts when forming their evaluations and attitudes towards the judiciary. Rather it was Correa's rhetoric and capacity to influence public opinion - that explained the increasing levels of trust in the judiciary that we are observing in Ecuador.

From a comparative perspective, this study has important implications for Latin America. Many countries in the region have historically had popular presidents that have sought to concentrate power and use their popularity to influence public opinion. Thus, it could be the case that support for the judiciary and, perhaps for other political institutions as well, is partly driven by executive approval. This is the case in Bolivia where president Evo Morales has actively sought to meddle with the judiciary and yet, an important proportion of citizens show that they trust Bolivian courts (Human Rights Watch 2019; Kaire 2019). Further research should devote attention to observe if the relationships outlined in this paper could be applied to other Latin American scenarios as well.

This paper seeks to bring attention to scholars studying attitudes towards political institutions, in general. If we want to know the roots of citizen support for institutions, we need to take into consideration individuals' experiences and perceptions with the other branches of government. This is specially the case in many democracies in Latin America, where a history of centralization of power and control of competing interests have created a culture of political monism (Dealy 1974). This has meant that presidents in these countries are regarded as the embodiment of the nation's interests and, therefore, represent what people want.

Finally, my argument speaks to the future of democracy in the Latin American region. Healthy democracies need citizens who value and care about a system of horizontal accountability. When citizens judge democratic institutions based 
mostly on the executive's performance this poses a threat to democracy because it implies that (some) individuals may support unrestrained presidential powers. To the extent that an important proportion of people are willing to unconditionally support popular presidents and their anti-democratic moves - such as Correa's 2011 judicial reform - this poses a severe threat to the future of democracy in the region.

\section{REFERENCES}

Basabe-Serrano, Santiago. 2013. "Rafael Correa: El Antes y El Después de La Política Ecuatoriana." Iberoamericana XIII(50): 168-73.

Basabe-Serrano, Santiago, and Julián Martínez. 2014. "Ecuador: Cada vez menos democracia, cada vez más autoritarismo... con elecciones." Revista de ciencia política (Santiago) 34(1): 145-70.

Benesh, Sara. 2006. "Understanding Public Confidence in American Courts." The Journal of Politics 68(3): 697-707.

Booth, John A., and Mitchell A. Seligson. 2009. The Legitimacy Puzzle in Latin America: Political Support and Democracy in Eight Nations. New York: Cambridge University Press.

Bühlmann, Marc, and Ruth Kunz. 2011. "Confidence in the Judiciary: Comparing the Independence and Legitimacy of Judicial Systems." West European Politics 34(2): 317-45.

Caldeira, Gregory, and James Gibson. 1992. "The Etiology of Public Support for the Supreme Court." American Journal of Political Science: 635-64.

Caldeira, Gregory, and James Gibson. 1995. "The Legitimacy of the Court of Justice in the European Union: Models of Institutional Support." The American Political Science Review 89: 356-76.

Cann, Damon, and Jeff Yates. 2008. "Homegrown Institutional Legitimacy." American Politics Research 36(2): 297-329.

Carlin, Ryan E., and Matthew M. Singer. 2011. "Support for Polyarchy in the Americas." Comparative Political Studies 44(11): 1500-1526.

Consejo de la Judicatura. 2013. Cumplimos: Rendición de Cuentas Julio 2011-Enero 2013. Quito. Rendición de Cuentas.

Consejo de la Judicatura. 2015. “Ecuatorianos Evalúan Positivamente a La Función Judicial, Según Revelan Estudios de Opinión Externos e Internos." http://www.funcionjudicial.gob.ec/index.php/es/saladeprensa/noticias/item/2127-ecuatorianos-evalúan-positivamente-a-la-función-judicial-según-revelan-estudios-de-opinión-externos-e-internos-con-versión-kichwa.html?tmpl=component\&print=1 Retrieved May 10, 2016.

Córdova, Ángel Polibio. 2019. La Fuerza de La Opinión Pública. Quito: CEDATOS.

Dealy, Glen Caudill. 1974. "The Tradition of Monistic Democracy in Latin America." Journal of the History of Ideas 35(4): 625.

Easton, David. 1975. "A Re-Assessment of the Concept of Political Support." British Journal of Political Science 5(4): 435-57.

El Universo. 2011. "'Sí, queremos meter las manos en las cortes.'” El Universo. https:/ /www. eluniverso.com/2011/01/09/1/1355/si-queremos-meter-manos-cortes.html Retrieved February 13, 2020.

Freidenberg, Flavia. 2012. “Ecuador 2011: Revolución Ciudadana, Estabilidad Presidencial y Personalismo Político." Revista de Ciencia Politica 32(1): 129-50.

Fundamedios. 2013. El Silencio Asfixiante: La Libertad de Expresión En El Ecuador 2013-2014. Quito, Ecuador.

Helmke, Gretchen, and Julio Rios-Figueroa, eds. 2011. Courts in Latin America. Cambridge University Press. 
Heras, Leticia. 2004. “Cultura Política y Democratización En América Latina." Revista de Ciencias Sociales (Cr) 1(103-104): 23-37.

Human Rights Watch. 2016. World Report: Ecuador.

Human Rights Watch. 2019. "Bolivia: Dozens of Judges Arbitrarily Dismissed." Human Rights Watch. https://www.hrw.org/news/2019/04/29/bolivia-dozens-judges-arbitrarily-dismissed Retrieved August 12, 2020.

Kaire, José. 2019. "The Normative and Material Foundations of Judicial Confidence in Bolivia." Latin American Politics and Society 61(04): 1-22.

Linzer, Drew A., and Jeffrey K. Staton. 2015. "Replication Data for: A Global Measure of Judicial Independence, 1948-2012." https:/ / dataverse.harvard.edu/dataset.xhtml?persistentId=doi:10.7910/DVN/L716E8 Retrieved October 12, 2017.

O’Donnell, Guillermo A. 1994. “Delegative Democracy." Journal of Democracy 5(1): 55-69.

Pásara, Luis. 2014. Independencia judicial en la reforma de la justicia ecuatoriana. [Lima]: Fundación para el Debido Proceso, Centro de Estudios de Derecho, Justicia y Sociedad, Instituto de Defensa Legal. http://www.justiciaviva.org.pe/webpanel/doc_int/ doc31072014-170324.pdf Retrieved May 9, 2016.

Salzman, Ryan, and Adam Ramsey. 2013. "Judging the Judiciary: Understanding Public Confidence in Latin American Courts." Latin American Politics and Society 55(1): 73-95.

SECOM. 2016. "Enlace Ciudadano No. 458."

Singer, Matthew M., and Ryan E. Carlin. 2013. "Context Counts: The Election Cycle, Development, and the Nature of Economic Voting." The Journal of Politics 75(3): 730-42.

de la Torre, Carlos. 2013. "El Tecnopopulismo de Rafael Correa: ¿Es Compatible El Carisma Con La Tecnocracia?" Latin American Research Review 48(1): 24-43.

Tyler, Tom R. 2006. Why People Obey The Law. New Jersey: Princeton University Press.

Walker, Lee Demetrius. 2016. "A Multi-Level Explanation of Mass Support for the Judiciary." Justice System Journal 37(3): 194-210.

Zechmeister, Elizabeth J., and Daniel Zizumbo-Colunga. 2013. "The Varying Political Toll of Concerns About Corruption in Good Versus Bad Economic Times." Comparative Political Studies 46(10): 1190-1218.

Received: December 17, 2018

Accepted: September 3, 2020

Paula Armendáriz Miranda is a Ph.D. candidate in political science at the University of Minnesota. Her work focuses on comparative political psychology. Specifically on the psychological roots of public support for authoritarian forms of government. She has contributed pieces for The Conversation and her work has been also recently accepted for publication at The Journal of Politics in Latin America. Email: armen013@umn.edu 


\section{APPENDIX}

\section{Questions used:}

Support for the judicial system: To what extent do you think the courts in Ecuador guarantee a fair trial? If you think the courts do not ensure justice at all, choose number 1; if you think the courts ensure justice a lot, choose number 7 , or choose a point in between the two.

Executive Approval: Speaking in general of the current administration, how would you rate the job performance of President Correa? (1) Very good (2) Good (3) Neither good nor bad (fair) (4) Bad (5) Very bad.

Experience with Courts: In the last twelve months, have you had any dealings with the courts?

National Economy: Do you think that the country's current economic situation is better than, the same as or worse than it was 12 months ago?

Personal Economy: Do you think that your economic situation is better than, the same as, or worse than it was 12 months ago?

Victim of corruption is an index combining the following variables: 1) Has a police officer asked you for a bribe in the last twelve months? 2) In the last twelve months, did any government employee ask you for a bribe? 3) In the last twelve months, to process any kind of document in your municipal government, like a permit for example, did you have to pay any money above that required by law? 4) In order to be seen in a hospital or a clinic in the last twelve months, did you have to pay a bribe? This yields an index with an alpha coefficient of 0.67.

Democracy: Changing the subject again, democracy may have problems, but it is better than any other form of government. To what extent do you agree or disagree with this statement?

Tolerance is also an index formed with the following variables: 1) There are people who only say bad things about the Ecuador's form of government, not just the current government but the system of government. 2) How strongly do you approve or disapprove of such people's right to vote? How strongly do you approve or disapprove that such people be allowed to conduct peaceful demonstrations in order to express their views? 3) Still thinking of those who only say bad things about the Ecuador's form of government, how strongly do you approve or disapprove of such people being permitted to run for public office? 4) How strongly do you approve or disapprove of such people appearing on television to make speeches? This yields an index with an alpha coefficient of 0.82 .

Education: How many years of schooling have you completed? 
Age: In what year were you born?

Income: the AmericasBarometer uses quintiles of wealth as a measure of respondent's income. This is constructed from a series of items where the interviewer asks: could you tell me if you have the following in your house: television, refrigerator, telephone, car, washing machines, microwave oven, indoor plumbing, indoor bathroom, computer? These are combined into a quintiles of wealth index using Principal Component Analysis following the procedures that the AmericasBarometer recommends. For more information on this see: Córdova, Abby. 2009. Measuring Relative Wealth using Household Asset Indicators and Principal Component Analysis (PCA). Insights Series 6. Nashville: Latin American Public Opinion Project, Vanderbilt University

Urban/Rural: the interviewer marks whether the respondent lives in an urban or rural area as specified by the census.

Sex: interviewer marks the respondent's sex without asking.

Table 1 presents summary statistics for the variables used in the paper. Note that all variables, except age, have been recoded to range from 0 to 1 . This does not mean that the variables were dichotomized. Rather, I recoded them so that the lowest possible value is 0 and the highest one is 1 .

Table 1. Summary Statistics

\begin{tabular}{lrrrrr}
\hline & N & Mean & St.Dev & min & \multicolumn{2}{c}{ max } \\
\hline Courts: Fair Trial & 16912 & .394 & .266 & 0 & 1 \\
Approval: President's Performance & 17773 & .552 & .25 & 0 & 1 \\
Correa's Vote & 9169 & .722 & .448 & 0 & 1 \\
Perception National Economy & 17702 & .377 & .363 & 0 & 1 \\
Perceived Personal Economy & 17687 & .427 & .347 & 0 & 1 \\
Corruption Victimization & 17964 & .271 & .444 & 0 & 1 \\
Experience with Courts & 17972 & .132 & .339 & 0 & 1 \\
Tolerance & 17715 & .469 & .245 & 0 & 1 \\
Values Democracy & 17169 & .647 & .283 & 0 & 1 \\
Years of Formal Education & 17904 & .575 & .233 & 0 & 1 \\
Respondent's Age & 17965 & 38.975 & 15.5 & 16 & 96 \\
Respondent's Quintiles of Wealth & 17990 & .477 & .349 & 0 & 1 \\
Urban/Rural & 17991 & .37 & .483 & 0 & 1 \\
Respondent's Sex & 17982 & .53 & .499 & 0 & 1 \\
\hline
\end{tabular}

Table 2 presents the full results for all the models presented in the paper. The first column ("Direct Effects") presents the results for the direct effect of executive approval on citizen trust in the judiciary. The second column ("Executive X Reform-Periods") presents the results for the interaction between executive approval and survey-years. The third column ("Full Interactions") shows the 
model where I interact executive approval, perceptions of the national economy, and experience with courts with survey-years (each one of these variables). The fourth column ("Correa's vote") is just a robustness check to see if those who voted for Rafael Correa had higher levels of trust in the judiciary, which as per the model's results - seems to be the case.

Table 2. Full Regression Results

\begin{tabular}{|c|c|c|c|c|}
\hline & $\begin{array}{l}\text { Direct } \\
\text { Effects }\end{array}$ & $\begin{array}{c}\text { Executive } X \\
\text { Reform-Periods }\end{array}$ & $\begin{array}{c}\text { Full } \\
\text { Interactions }\end{array}$ & $\begin{array}{c}\text { Correa's } \\
\text { vote }\end{array}$ \\
\hline $\begin{array}{l}\text { Approval: President's } \\
\text { Performance }\end{array}$ & $0.161^{* * *}$ & $0.112^{* * *}$ & $0.117^{* * *}$ & \\
\hline & $(0.013)$ & $(0.027)$ & $(0.027)$ & \\
\hline Correa's Vote & & & & $\begin{array}{l}0.047^{* * *} \\
(0.008)\end{array}$ \\
\hline Perception National Economy & $\begin{array}{l}0.031^{* * *} \\
(0.009)\end{array}$ & $\begin{array}{l}0.023^{* *} \\
(0.008)\end{array}$ & $\begin{array}{r}0.001 \\
(0.016)\end{array}$ & $\begin{array}{l}0.057^{* * *} \\
(0.011)\end{array}$ \\
\hline Perceived Personal Economy & $\begin{array}{r}0.015 \\
(0.008)\end{array}$ & $\begin{array}{r}0.013 \\
(0.008)\end{array}$ & $\begin{array}{r}0.012 \\
(0.008)\end{array}$ & $\begin{array}{r}0.028^{*} \\
(0.011)\end{array}$ \\
\hline Corruption Victimization & $\begin{array}{l}-0.019^{* *} \\
(0.006)\end{array}$ & $\begin{array}{r}-0.020^{* * *} \\
(0.006)\end{array}$ & $\begin{array}{l}-0.020^{* *} \\
(0.006)\end{array}$ & $\begin{array}{l}-0.018^{*} \\
(0.008)\end{array}$ \\
\hline Experience with Courts & $\begin{array}{l}-0.018^{*} \\
(0.008)\end{array}$ & $\begin{array}{l}-0.021^{* *} \\
(0.008)\end{array}$ & & $\begin{array}{r}-0.013 \\
(0.011)\end{array}$ \\
\hline Tolerance & $\begin{array}{r}0.026^{*} \\
(0.012)\end{array}$ & $\begin{array}{l}0.031^{* *} \\
(0.012)\end{array}$ & $\begin{array}{l}0.032^{* *} \\
(0.012)\end{array}$ & $\begin{array}{r}0.011 \\
(0.015)\end{array}$ \\
\hline Values Democracy & $\begin{array}{l}0.032^{* *} \\
(0.010)\end{array}$ & $\begin{array}{l}0.027^{* *} \\
(0.010)\end{array}$ & $\begin{array}{l}0.027^{* *} \\
(0.010)\end{array}$ & $\begin{array}{r}0.027^{*} \\
(0.013)\end{array}$ \\
\hline Years of Formal Education & $\begin{array}{l}-0.084^{* * *} \\
(0.014)\end{array}$ & $\begin{array}{r}-0.079^{* * *} \\
(0.014)\end{array}$ & $\begin{array}{l}-0.079^{* * *} \\
(0.014)\end{array}$ & $\begin{array}{l}-0.076^{* * *} \\
(0.018)\end{array}$ \\
\hline Respondent's Age & $\begin{array}{c}-0.001^{* * *} \\
(0.000)\end{array}$ & $\begin{array}{r}-0.001^{* * *} \\
(0.000)\end{array}$ & $\begin{array}{r}-0.001^{* * *} \\
(0.000)\end{array}$ & $\begin{array}{l}-0.001^{* * *} \\
(0.000)\end{array}$ \\
\hline $\begin{array}{l}\text { Respondent's Quintiles of } \\
\text { Wealth }\end{array}$ & $\begin{array}{l}-0.007 \\
(0.009)\end{array}$ & $\begin{array}{l}-0.006 \\
(0.009)\end{array}$ & $\begin{array}{l}-0.006 \\
(0.009)\end{array}$ & $\begin{array}{l}-0.007 \\
(0.012)\end{array}$ \\
\hline Urban/Rural & $\begin{array}{l}0.021^{* *} \\
(0.007)\end{array}$ & $\begin{array}{l}0.021^{* *} \\
(0.007)\end{array}$ & $\begin{array}{l}0.021^{* *} \\
(0.007)\end{array}$ & $\begin{array}{l}0.023^{* *} \\
(0.008)\end{array}$ \\
\hline
\end{tabular}




\begin{tabular}{|c|c|c|c|c|}
\hline & $\begin{array}{l}\text { Direct } \\
\text { Effects }\end{array}$ & $\begin{array}{c}\text { Executive X } \\
\text { Reform-Periods }\end{array}$ & $\begin{array}{c}\text { Full } \\
\text { Interactions }\end{array}$ & $\begin{array}{l}\text { Correa's } \\
\text { vote }\end{array}$ \\
\hline Respondent's Sex & $\begin{array}{l}0.011^{* *} \\
(0.004)\end{array}$ & $\begin{array}{c}0.011^{* *} \\
(0.004)\end{array}$ & $\begin{array}{l}0.012^{* *} \\
(0.004)\end{array}$ & $\begin{array}{l}0.022^{+* *+} \\
(0.006)\end{array}$ \\
\hline 2004 & $\begin{array}{r}0.000 \\
(.)\end{array}$ & & & \\
\hline 2006 & $\begin{array}{r}0.011 \\
(0.017)\end{array}$ & & & \\
\hline 2008 & $\begin{array}{r}-0.007 \\
(0.012)\end{array}$ & & & $\begin{array}{r}0.000 \\
(.)\end{array}$ \\
\hline 2010 & $\begin{array}{l}-0.015 \\
(0.011)\end{array}$ & & & $\begin{array}{r}-0.008 \\
(0.012)\end{array}$ \\
\hline 2012 & $\begin{array}{l}0.053^{* * *} \\
(0.015)\end{array}$ & & & $\begin{array}{l}0.069^{* * *} \\
(0.017)\end{array}$ \\
\hline 2014 & $\begin{array}{l}0.067^{* * *} \\
(0.012)\end{array}$ & & & $\begin{array}{l}0.087^{* * *} \\
(0.013)\end{array}$ \\
\hline 2016 & $\begin{array}{l}0.090^{* * *} \\
(0.010)\end{array}$ & & & $\begin{array}{l}0.112^{* * *} \\
(0.013)\end{array}$ \\
\hline 2019 & $\begin{array}{l}0.095^{* * *} \\
(0.012)\end{array}$ & & & $\begin{array}{l}0.092^{* * *} \\
(0.014)\end{array}$ \\
\hline
\end{tabular}

Pre-Correa

$0.000 \quad 0.000$

(.) (.)

$\begin{array}{lll}\text { Correa Pre-Reform } & -0.011 & -0.019\end{array}$

$(0.020) \quad(0.020)$

Correa Post-Reform

$0.002-0.000$

$(0.020) \quad(0.020)$

Post-Correa

$\begin{array}{ll}0.073^{* * *} & 0.069^{* *} \\ (0.022) & (0.022)\end{array}$

Pre-Correa \# Approval:

President's Performance

$0.000 \quad 0.000$

(.) (.)

Correa Pre-Reform \#

Approval: President's

$0.009 \quad 0.005$

Performance 


\begin{tabular}{cccc}
\hline Direct & Executive X & Full & Correa's \\
Effects & Reform-Periods & Interactions & vote \\
\hline
\end{tabular}

Correa Post-Reform \#

Approval: President's

$0.115^{* * *} \quad 0.102^{* *}$

Performance

(0.033) (0.034)

Post-Correa \# Approval:

President's Performance

$0.038 \quad 0.030$

(0.039) (0.041)

No experience

0.000

Experience

No experience \# Pre-Correa

No experience \# Correa Pre-

Reform

No experience \# Correa Post-

Reform

No experience \# Post-Correa

0.000

Experience \# Pre-Correa

Experience \# Correa PreReform

Experience \# Correa Post-

Reform

Pre-Correa \# Perception

National Economy 


\begin{tabular}{|c|c|c|c|c|}
\hline & $\begin{array}{l}\text { Direct } \\
\text { Effects }\end{array}$ & $\begin{array}{c}\text { Executive } \mathrm{X} \\
\text { Reform-Periods }\end{array}$ & $\begin{array}{c}\text { Full } \\
\text { Interactions }\end{array}$ & $\begin{array}{c}\text { Correa's } \\
\text { vote }\end{array}$ \\
\hline $\begin{array}{l}\text { Correa Pre-Reform \# } \\
\text { Perception National Economy }\end{array}$ & & & $\begin{array}{r}0.021 \\
(0.022)\end{array}$ & \\
\hline $\begin{array}{l}\text { Correa Post-Reform \# } \\
\text { Perception National Economy }\end{array}$ & & & $\begin{array}{r}0.033 \\
(0.020)\end{array}$ & \\
\hline $\begin{array}{l}\text { Post-Correa \# Perception } \\
\text { National Economy }\end{array}$ & & & $\begin{array}{r}0.029 \\
(0.028) \\
\end{array}$ & \\
\hline Observations & 15433 & 15433 & 15433 & 7967 \\
\hline
\end{tabular}

Standard errors in parentheses

${ }^{*} p<0.05,{ }^{* *} p<0.01,{ }^{* * *} p<0.001$

Table 3 presents the same results as above but with an ordered logit model instead of OLS.

Table 3. Ordered Logit Models

\begin{tabular}{lcccc}
\hline & $\begin{array}{c}\text { Direct } \\
\text { Effects }\end{array}$ & $\begin{array}{c}\text { Executive } \\
\text { Interaction }\end{array}$ & $\begin{array}{c}\text { Full } \\
\text { Interactions }\end{array}$ & $\begin{array}{c}\text { Correa's } \\
\text { vote }\end{array}$ \\
\hline $\begin{array}{l}\text { Approval: President's } \\
\text { Performance }\end{array}$ & $\left(0.205^{* * *}\right.$ & $0.911^{* * *}$ & $0.951^{* * *}$ & \\
& & $(0.204)$ & $(0.210)$ & \\
Correa's Vote & & & & $0.335^{* * *}$ \\
& & & & $(0.054)$ \\
Perception National Economy & $0.225^{* * *}$ & $0.171^{* * *}$ & 0.017 & $0.419^{* * *}$ \\
& $(0.060)$ & $(0.059)$ & $(0.115)$ & $(0.079)$ \\
Perceived Personal Economy & 0.101 & 0.084 & 0.082 & $0.185^{*}$ \\
& $(0.059)$ & $(0.059)$ & $(0.059)$ & $(0.079)$ \\
Corruption Victimization & & & & $-0.138^{*}$ \\
& $-0.142^{* * *}$ & $-0.146^{* * *}$ & $-0.145^{* * *}$ & $(0.059)$ \\
Experience with Courts & $(0.043)$ & $(0.043)$ & $(0.043)$ & -0.122 \\
& & & & $(0.076)$ \\
Tolerance & $-0.143^{* *}$ & $-0.170^{* *}$ & & 0.113 \\
& $(0.054)$ & $(0.054)$ & & $(0.110)$ \\
\hline
\end{tabular}




\begin{tabular}{|c|c|c|c|c|}
\hline & $\begin{array}{l}\text { Direct } \\
\text { Effects }\end{array}$ & $\begin{array}{l}\text { Executive } \\
\text { Interaction }\end{array}$ & $\begin{array}{c}\text { Full } \\
\text { Interactions }\end{array}$ & $\begin{array}{l}\text { Correa's } \\
\text { vote }\end{array}$ \\
\hline \multirow[t]{2}{*}{ Values Democracy } & $0.228^{* *}$ & $0.189^{*}$ & $0.188^{*}$ & $0.208^{*}$ \\
\hline & $(0.074)$ & $(0.075)$ & $(0.075)$ & $(0.097)$ \\
\hline \multirow[t]{2}{*}{ Years of Formal Education } & $-0.520^{* * *+}$ & $-0.483^{* * *}$ & $-0.479^{* * *}$ & $-0.485^{* * *}$ \\
\hline & $(0.096)$ & $(0.097)$ & $(0.096)$ & $(0.129)$ \\
\hline \multirow[t]{2}{*}{ Respondent's Age } & $-0.008^{* * *}$ & $-0.008^{* * *}$ & $-0.008^{* * *}$ & $-0.008^{* * *}$ \\
\hline & $(0.001)$ & $(0.001)$ & $(0.001)$ & $(0.002)$ \\
\hline \multirow[t]{2}{*}{ Respondent's Quintiles of Wealth } & -0.041 & -0.034 & -0.034 & -0.026 \\
\hline & $(0.065)$ & $(0.065)$ & $(0.065)$ & $(0.083)$ \\
\hline \multirow[t]{2}{*}{ Urban/Rural } & $0.151^{* *}$ & $0.155^{* * *}$ & $0.153^{* *}$ & $0.162^{* *}$ \\
\hline & $(0.046)$ & $(0.047)$ & $(0.047)$ & $(0.053)$ \\
\hline \multirow[t]{2}{*}{ Respondent's Sex } & $0.072^{*}$ & $0.071^{*}$ & $0.073^{*}$ & $0.145^{* * *}$ \\
\hline & $(0.030)$ & $(0.030)$ & $(0.030)$ & $(0.041)$ \\
\hline \multirow[t]{2}{*}{2004} & 0.000 & & & \\
\hline & (.) & & & \\
\hline \multirow[t]{2}{*}{2006} & 0.100 & & & \\
\hline & $(0.121)$ & & & \\
\hline \multirow[t]{2}{*}{2008} & -0.022 & & & 0.000 \\
\hline & $(0.087)$ & & & (.) \\
\hline \multirow[t]{2}{*}{2010} & -0.061 & & & -0.039 \\
\hline & $(0.077)$ & & & $(0.091)$ \\
\hline \multirow[t]{2}{*}{2012} & $0.377^{* * * *}$ & & & $0.479^{* * *+}$ \\
\hline & $(0.111)$ & & & $(0.128)$ \\
\hline \multirow[t]{2}{*}{2014} & $0.482^{* * *}$ & & & $0.608^{* * *}$ \\
\hline & $(0.083)$ & & & $(0.097)$ \\
\hline \multirow[t]{2}{*}{2016} & $0.652^{* * *}$ & & & $0.781^{* * *}$ \\
\hline & $(0.073)$ & & & $(0.095)$ \\
\hline \multirow[t]{2}{*}{2019} & $0.679^{* * *}$ & & & $0.627^{* * *}$ \\
\hline & $(0.079)$ & & & $(0.099)$ \\
\hline \multirow[t]{2}{*}{ Pre-Correa } & & 0.000 & 0.000 & \\
\hline & & (.) & (.) & \\
\hline \multirow[t]{2}{*}{ Correa Pre-Reform } & & -0.017 & -0.074 & \\
\hline & & $(0.151)$ & $(0.153)$ & \\
\hline
\end{tabular}




\begin{tabular}{ccccc}
\hline & Direct & Executive & Full & Correa's \\
Effects & Interaction & Interactions & vote \\
\hline
\end{tabular}

Correa Post-Reform

$\begin{array}{rr}0.045 & 0.027 \\ (0.148) & (0.148)\end{array}$

Post-Correa

$\begin{array}{ll}0.552^{* * *} & 0.525^{* *} \\ (0.156) & (0.157)\end{array}$

(0.156) (0.157)

Pre-Correa \# Approval:

President's Performance

$0.000 \quad 0.000$

(.) (.)

Correa Pre-Reform \# Approval:

President's Performance

$-0.013 \quad-0.046$

$(0.255) \quad(0.265)$

Correa Post-Reform \# Approval:

President's Performance

$0.746^{* *} \quad 0.657^{*}$

$(0.249) \quad(0.260)$

Post-Correa \# Approval:

President's Performance

$0.171 \quad 0.118$

(0.285) (0.302)

No experience

0.000

Experience

No experience \# Pre-Correa

No experience \# Correa PreReform

No experience \# Correa Post-

Reform

No experience \# Post-Correa

0.000

Experience \# Pre-Correa

0.000

Experience \# Correa Pre-Reform 


\begin{tabular}{|c|c|c|c|c|}
\hline & $\begin{array}{l}\text { Direct } \\
\text { Effects }\end{array}$ & $\begin{array}{l}\text { Executive } \\
\text { Interaction }\end{array}$ & $\begin{array}{c}\text { Full } \\
\text { Interactions }\end{array}$ & $\begin{array}{l}\text { Correa's } \\
\text { vote }\end{array}$ \\
\hline Experience \# Correa Post-Reform & & & $\begin{array}{r}-0.063 \\
(0.140)\end{array}$ & \\
\hline Experience \# Post-Correa & & & $\begin{array}{r}-0.060 \\
(0.194)\end{array}$ & \\
\hline $\begin{array}{l}\text { Pre-Correa \# Perception National } \\
\text { Economy }\end{array}$ & & & $\begin{array}{r}0.000 \\
(.)\end{array}$ & \\
\hline $\begin{array}{l}\text { Correa Pre-Reform \# Perception } \\
\text { National Economy }\end{array}$ & & & $\begin{array}{r}0.160 \\
(0.158)\end{array}$ & \\
\hline $\begin{array}{l}\text { Correa Post-Reform \# Perception } \\
\text { National Economy }\end{array}$ & & & $\begin{array}{r}0.226 \\
(0.142)\end{array}$ & \\
\hline $\begin{array}{l}\text { Post-Correa \# Perception National } \\
\text { Economy }\end{array}$ & & & $\begin{array}{r}0.191 \\
(0.192) \\
\end{array}$ & \\
\hline Observations & 15433 & 15433 & 15433 & 7967 \\
\hline
\end{tabular}

Standard errors in parentheses

" $p<0.05,{ }^{* *} p<0.01,{ }^{* * *} p<0.001$

Table 4 presents the same set of OLS models but using the variable that asks respondents "To what extent do you trust the justice system?" as a dependent variable. This variable is measured on a 7-point scale where 1 means that the respondent does not trust at all and 7 that the respondent trusts a lot.

Table 4. Trust in Justice System as Outcome

\begin{tabular}{lcccc}
\hline & $\begin{array}{c}\text { Direct } \\
\text { Effects }\end{array}$ & $\begin{array}{c}\text { Executive } \\
\text { Interaction }\end{array}$ & $\begin{array}{c}\text { Full } \\
\text { Interactions }\end{array}$ & $\begin{array}{c}\text { Correa's } \\
\text { vote }\end{array}$ \\
\hline $\begin{array}{l}\text { Approval: President's } \\
\text { Performance }\end{array}$ & $0.218^{*+*}$ & $0.190^{* *+*}$ & $0.198^{*+*}$ & \\
& $(0.017)$ & $(0.039)$ & $(0.039)$ & \\
Correa's Vote & & & & $0.064^{* * *}$ \\
& & & & $(0.009)$ \\
Perception National Economy & $0.030^{* *}$ & $0.031^{* *}$ & -0.023 & $0.063^{* * *}$ \\
& $(0.011)$ & $(0.011)$ & $(0.027)$ & $(0.014)$ \\
Perceived Personal Economy & & & & \\
& $0.028^{*}$ & $0.028^{*}$ & $0.026^{*}$ & $0.038^{* *}$ \\
& $(0.011)$ & $(0.011)$ & $(0.011)$ & $(0.013)$ \\
\hline
\end{tabular}




\begin{tabular}{|c|c|c|c|c|}
\hline & $\begin{array}{l}\text { Direct } \\
\text { Effects }\end{array}$ & $\begin{array}{l}\text { Executive } \\
\text { Interaction } \\
\end{array}$ & $\begin{array}{c}\text { Full } \\
\text { Interactions } \\
\end{array}$ & $\begin{array}{c}\text { Correa's } \\
\text { vote }\end{array}$ \\
\hline Corruption Victimization & $\begin{array}{l}-0.027^{+4+4} \\
(0.007)\end{array}$ & $\begin{array}{l}-0.027^{*+*} \\
(0.007)\end{array}$ & $\begin{array}{r}-0.026^{* *+4} \\
(0.007)\end{array}$ & $\begin{array}{c}-0.032^{*+1} \\
(0.009)\end{array}$ \\
\hline Experience with Courts & $\begin{array}{r}-0.011 \\
(0.010)\end{array}$ & $\begin{array}{r}-0.015 \\
(0.010)\end{array}$ & & $\begin{array}{r}-0.011 \\
(0.012)\end{array}$ \\
\hline Tolerance & $\begin{array}{r}-0.020 \\
(0.014)\end{array}$ & $\begin{array}{r}-0.018 \\
(0.014)\end{array}$ & $\begin{array}{r}-0.017 \\
(0.014)\end{array}$ & $\begin{array}{c}-0.047^{*} \\
(0.018)\end{array}$ \\
\hline Values Democracy & $\begin{array}{r}0.027^{*} \\
(0.013)\end{array}$ & $\begin{array}{r}0.027^{*} \\
(0.014)\end{array}$ & $\begin{array}{r}0.025 \\
(0.013)\end{array}$ & $\begin{array}{r}0.038 \\
(0.018)\end{array}$ \\
\hline Years of Formal Education & $\begin{array}{l}-0.061^{1+*++} \\
(0.017)\end{array}$ & $\begin{array}{l}-0.058^{*+*+} \\
(0.017)\end{array}$ & $\begin{array}{r}-0.059^{* *+*} \\
(0.017)\end{array}$ & $\begin{array}{l}-0.056 \\
(0.022)\end{array}$ \\
\hline Respondent's Age & $\begin{array}{l}-0.001^{*+*+} \\
(0.000)\end{array}$ & $\begin{array}{l}-0.001^{* *+*} \\
(0.000)\end{array}$ & $\begin{array}{r}-0.001^{* *+*} \\
(0.000)\end{array}$ & $\begin{array}{c}-0.001^{*+*} \\
(0.000)\end{array}$ \\
\hline $\begin{array}{l}\text { Respondent's Quintiles of } \\
\text { Wealth }\end{array}$ & $\begin{array}{r}0.002 \\
(0.011)\end{array}$ & $\begin{array}{r}0.002 \\
(0.011)\end{array}$ & $\begin{array}{r}0.000 \\
(0.011)\end{array}$ & $\begin{array}{r}-0.004 \\
(0.014)\end{array}$ \\
\hline Urban/Rural & $\begin{array}{c}0.025^{* *} \\
(0.009)\end{array}$ & $\begin{array}{l}0.024^{* *} \\
(0.009)\end{array}$ & $\begin{array}{l}0.025^{* *} \\
(0.009)\end{array}$ & $\begin{array}{r}0.018 \\
(0.010)\end{array}$ \\
\hline Respondent's Sex & $\begin{array}{r}0.006 \\
(0.006)\end{array}$ & $\begin{array}{r}0.006 \\
(0.006)\end{array}$ & $\begin{array}{r}0.006 \\
(0.006)\end{array}$ & $\begin{array}{r}0.008 \\
(0.007)\end{array}$ \\
\hline 2006 & $\begin{array}{r}0.000 \\
(.)\end{array}$ & & $\begin{array}{r}0.000 \\
(.)\end{array}$ & \\
\hline 2008 & $\begin{array}{r}0.016 \\
(0.015)\end{array}$ & & $\begin{array}{l}-0.044^{*} \\
(0.018)\end{array}$ & $\begin{array}{r}0.000 \\
(.)\end{array}$ \\
\hline 2010 & $\begin{array}{l}0.042^{* *} \\
(0.014)\end{array}$ & & $\begin{array}{r}0.000 \\
(.)\end{array}$ & $\begin{array}{r}0.027 \\
(0.012)\end{array}$ \\
\hline 2012 & $\begin{array}{l}0.086^{* *+*} \\
(0.017)\end{array}$ & & $\begin{array}{r}-0.000 \\
(0.027)\end{array}$ & $\begin{array}{l}0.081^{* * *} \\
(0.015)\end{array}$ \\
\hline 2014 & $\begin{array}{l}0.112^{* * *} \\
(0.018)\end{array}$ & & $\begin{array}{r}0.000 \\
\quad(.)\end{array}$ & $\begin{array}{l}0.121^{* * *} \\
(0.017)\end{array}$ \\
\hline Pre-Correa & & $\begin{array}{r}0.000 \\
(.)\end{array}$ & $\begin{array}{r}0.000 \\
(.)\end{array}$ & \\
\hline Correa Pre-Reform & & $0.051^{*}$ & $0.060^{*}$ & \\
\hline
\end{tabular}




\begin{tabular}{cccc}
\hline Direct & Executive & Full & Correa's \\
Effects & Interaction & Interactions & vote \\
\hline
\end{tabular}

Correa Post-Reform

$\begin{array}{rr}0.040 & 0.026 \\ (0.030) & (0.034)\end{array}$

Pre-Correa \# Approval:

President's Performance

$0.000 \quad 0.000$

(.) (.)

Correa Pre-Reform \# Approval:

President's Performance

$-0.025 \quad-0.036$

(0.044) (0.044)

Correa Post-Reform \# Approval: President's $\begin{array}{ll}0.098^{*} & 0.085\end{array}$

Performance

(0.048) (0.049)

No experience

0.000

Experience

0.013

(0.023)

No experience \# 2006

0.000

(.)

No experience \# 2008

0.000

(.)

No experience \# 2010

0.000

(.)

No experience \# 2012

0.000

(.)

No experience \# 2014

0.000

(.)

Experience \# 2006

0.000

(.)

Experience \# 2008

Experience \# 2010 


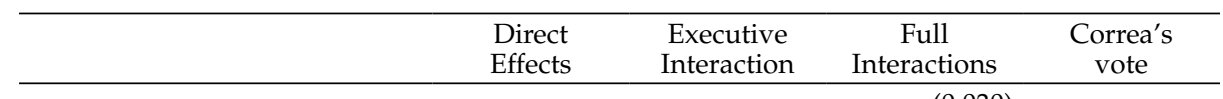
(0.030)

Experience \# 2014

$-0.021$

(0.031)

2006 \# Perception National Economy

0.000

(.)

2008 \# Perception National Economy

2010 \# Perception National Economy

2012 \# Perception National Economy

2014 \# Perception National Economy

Standard errors in parentheses ${ }^{*} p<0.05,{ }^{* *} p<0.01,{ }^{* * *} p<0.001$ 